\title{
Manual Vacuum Aspiration in IUFD 18 Weeks
}

\author{
Aspirasi Vakum Manual pada IUFD 18 Minggu
}

\author{
Ivanna Beru Brahmana* \\ Department of Obstetrics and Gynecology, Medical Study Program, Faculty of Medicine and Health Sciences, Universitas \\ Muhammadiyah Yogyakarta
}

DATA OF ARTICLE:

Received: 13 April 2021

Reviewed: 3 July 2021

Revised: 12 July 2021

Accepted: 25 July 2021

*CORRESPONDENCE:

ivanna_beru_brahmana@yahoo.com

DOI:

10.18196/mmjkk.v21i2.10238

TYPE OF ARTICLE:

Case Report

\begin{abstract}
Manual Vacuum Aspiration (MVA) is an action to evacuate the uterine cavity up to 14 weeks gestation. In a more extensive pregnancy, it is worried that the action of the MVA is less clean so that it will still repeat the action of sharp curettage. This article reports a multigravida aged 42 years old, G5P2A2, intrauterine fetal death (IUFD) at 18 weeks, undergoing MVA. Diagnosis of IUFD was performed using ultrasound examination. Before MVA was done, the patient was previously given 100 $\mu \mathrm{g}$ of misoprostol orally for dilation. This pregnancy was the third pregnancy with a second husband, all of whom had abortions. Manual Vacuum Aspiration had a minimal risk of uterine injury. After MVA was conducted, ultrasound examination was repeated to confirm a clean uterine cavity. It had been carried out on an indication of IUFD of 18 weeks gestation with the result of a clean uterine cavity and minimal bleeding. Furthermore, Post-Abortion Intra-Uterine Device (PAIUD) was installed adequately, not causing complaints. Based on the result, it can be concluded that MVA is effective for evacuation of uterine cavities on 18 weeks gestation.
\end{abstract}

Keywords: multigravida; manual vacuum aspiration; intrauterine fetal death

Abstrak: Aspirasi vakum manual (AVM) merupakan tindakan untuk evakuasi
kavum uteri hingga usia kehamilan 14 minggu. Oleh karena pada kehamilan yang
lebih besar dikhawatirkan tindakan AVM kurang bersih, sehingga masih
menimbulkan gejala sisa berupa perdarahan, yang mungkin harus diulang dengan
tindakan kuretase tajam. Artikel ini menyampaikan case report seorang
multigravida berusia 42 tahun, G5P2A2 hamil 18 minggu dengan intra uterine
fetal death (IUFD), yang menjalani AVM untuk evakuasi kavum uteri. Diagnosis
IUFD dengan menggunakan pemeriksaan Ultra Sono Grafi (USG). Sebelum
tindakan AVM diberikan misoprostol 100 pg per oral untuk dilatasi. Kehamilan
ini adalah kehamilan ketiga dengan suami kedua, yang semuanya abortus. AVM
berisiko minimal terjadi perlukaan uterus. Setelah tindakan AVM, bersih tidaknya
kavum uteri dievaluasi dengan menggunakan pemeriksaan USG. Sudah dilakukan
AVM atas indikasi IUFD usia kehamilan 18 minggu dengan hasil kavum uteri
bersih, perdarahan minimal, IUD paska abortus (IUDPA) yang dipasang terpasang
dengan baik, tidak menimbulkan keluhan. Aspirasi Vakum Manual (AVM) efektif
untuk tindakan evakuasi kavum uteri untuk usia kehamilan 18 minggu.

Kata Kunci : multigravida; aspirasi vakum manual; intra uterine fetal death 


\section{INTRODUCTION}

Manual Vacuum Aspiration (MVA) is an act of evacuation of the uterine cavity by vacuuming instead of being scraped off with a curettage spoon. This vacuuming action is expected not to damage the endometrial layer compared to evacuation using a curettage spoon. The expected long-term effect of vacuuming is no placental adhesions for the subsequent pregnancy. The use of MVA reduces the likelihood of symptomatic synechiae occurrences. ${ }^{1}$ Therefore, the risk of the placenta sticking to its insertion, called placenta accreta, is a medical indication that increases the risk of morbidity and mortality in pregnant women. Intrauterine Fetal Death (IUFD) is the condition of the death of the fetus in the womb because the fetal heart rate is no longer detected. Several factors causing fetal death, in this case, may be due to maternal age over 40 years. ${ }^{2}$ IUFD conditions require immediate evacuation of the uterine cavity. The amount of gestational age of 18 weeks is measured as high as 3 fingers below the center. The amount of gestational age requires proper uterine cavity evacuation. Evacuation of the uterine cavity using MVA is indicated for the evacuation of the uterine cavity until 14 weeks gestation ${ }^{3}$ or not more than 12 week's gestation. ${ }^{4}$

This paper is a case report about the evacuation of uterine cavities in IUFD cases at 18 weeks gestation using MVA preceded by administration of $100 \mu \mathrm{g}$ misoprostol orally for dilation. This case is interesting as the respondents experienced $3 x$ pregnancies, all of which experienced abortions. All three pregnancies were from a marriage with a second husband and had no children born healthy. AVM has a minimal risk of injuring the endometrium. AVM action was chosen to minimize endometrial injury as the respondent still expected to get pregnant with healthy fetal development. Meanwhile, AVM is usually done at a gestational age of no more than 12 or 14 weeks. ${ }^{4}$

MVA was firstly described in the 1970s. MVA is an action used in the handling of incomplete abortion. This action is widely used in the United States of America (USA), Asia, Europe, and Africa. ${ }^{5}$ Many centers have not applied MVA to evacuate the uterine cavity yet. Therefore, the use of MVA in clinical practice has not mainly been reported. ${ }^{6}$ England is one of the countries that has not used MVA much to manage uterine cavity evacuation. Based on that reason, Speedie et al. felt the need to promote the use of MVA' ${ }^{7}$ MVA is an alternative action for the evacuation of the uterine cavity in cases of an incomplete abortion. ${ }^{8}$

Incomplete abortion is a miscarriage of the resultant conception that has not entirely come out of the uterine cavity but is still partly in the uterine cavity. ${ }^{8,9}$ If an abortion occurs, incompleteness can increase maternal morbidity. ${ }^{9}$ Studies comparing $400 \mu$ g of sublingual misoprostol with MVA showed that misoprostol is analogous to MVA as the first line in managing incomplete abortion. ${ }^{9}$ The advantages of using MVA for the evacuation of uterine cavities are that MVA is safer, less painful, and more cost-effective than sharp curettage. More importantly, MVA has a lower risk of uterine perforation than sharp curettage. MVA measures cannot be applied in the operating room merely but can be done in the clinic or emergency room. ${ }^{8}$

\section{CASES}

The patient was a multigravida aged 42-year-old with 18 weeks gestation presented with IUFD. She was in the 3 rd PoA2 pregnancy from her second husband. With the first husband, the patient already had two healthy growing children, $\mathrm{P}_{2} \mathrm{Ao}$. History of obstetrics with a second husband as $\mathrm{G}_{3} \mathrm{P} 0 \mathrm{~A} 2$ included the first and second pregnancy abortion in 2017 and 2018, performed curettage. The third pregnancy underwent an IUFD and performed MVA.

The oral misoprostol $100 \mathrm{~g}$ was given previously for dilation, which then appeared to be profuse bleeding. The AVM was then performed in the operating room under anesthesia. After the AVM procedure was declared clean, the Post-Abortion Intra-Uterine Device (PAIUD) was installed to handle the evacuation of the uterine cavity and rest the uterus for at least the next six months. Complaints of bleeding had been felt three days before entering the hospital. When more blood came out, the patient went to a midwife before being referred to the hospital emergency Installation. Doctors after examining the patient, providing therapy: allylestrenol $2 \times 1$ and isoxsuprine $3 \times 1 / 2$ tablet. The patient was discharged. Two days later, more and more bleeding occurred about two hours before being admitted to the hospital. The patient no longer felt fetal movements. 

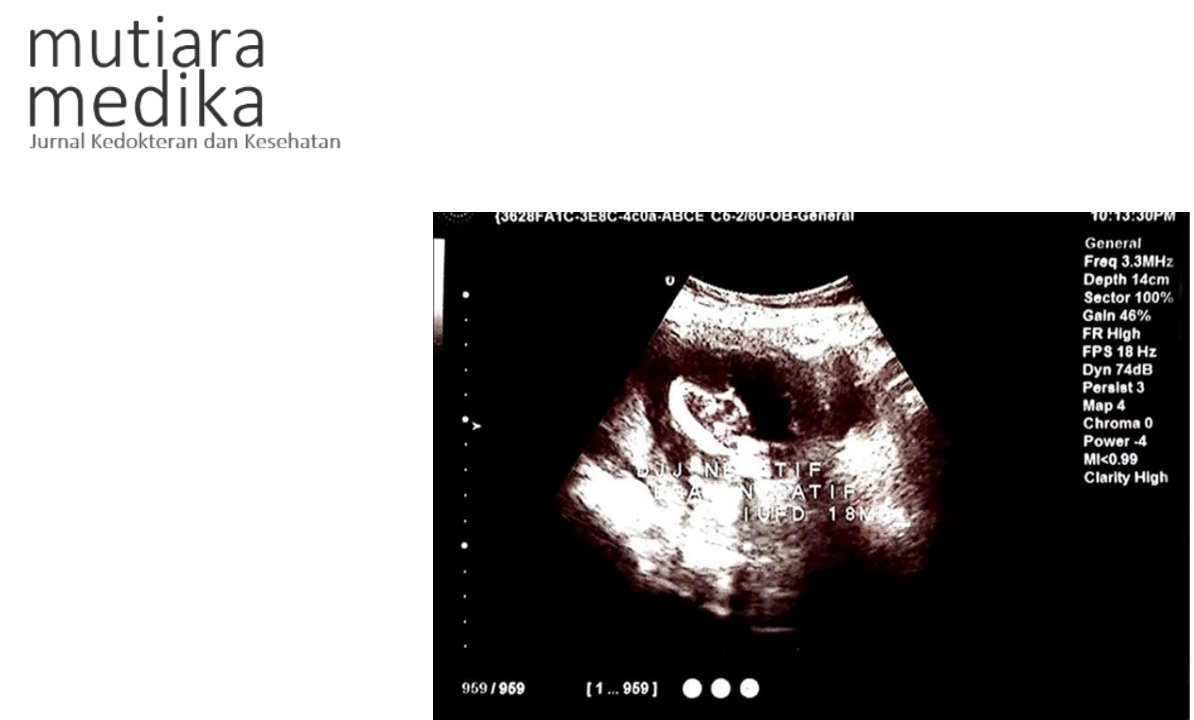

Figure 1. Ultrasound results: a single fetus, spalding sign (+), FHR (-), diagnosed with IUFD

When vaginal bleeding got worse, it was decided to do an MVA emergency action. The patient stopped eating and drinking. The patient's general condition was good, with a high fundus uterine of 3 central lower fingers. During the implementation of the MVA, they planned to conduct PAIUD. After the fetus has been removed with forceps, the bleeding before MVA was $200 \mathrm{ml}$. Meanwhile, the fetus \& part of the placenta appeared. MVA was performed with a $12 \mathrm{~cm}$ sondage and anteflexed uterus (AF). It lasted for 10 minutes and obtained as much as $50 \mathrm{ml}$ of tissue residue and $50 \mathrm{ml}$ of bleeding. After the MVA action was recondensed, uterine depth was $11 \mathrm{~cm}$, and $\mathrm{Cu}$-T type PAIUD was continued. PAIUD was the most preferred type of contraception (58.6\%) after MVA compared to other types, namely: pills (16.4\%), implants (13.5\%), injections $(7.9 \%)$, and condoms $(1,3 \%) .{ }^{10}$ The installation of a PAIUD was intended to rest the uterus postabortion for at least six months. Meanwhile, the tracking phase can be done, within 6 months, to cause abortion and its treatment. The patient would also be psychologically calmer to prepare for the subsequent pregnancy. The contraception was chosen as an IUFD because it was non-hormonal, so it did not interfere with menstruation. The patient's fertility returned immediately after the release of the IUFD. Besides, the IUFD was long-term contraception. Thus, if within 6 months the patient was not ready to get pregnant again, then the contraceptive still maintained the desire of family planning from the patient.

\section{Post MVA}

The patient's general condition was still anesthetized, with vital signs: blood pressure 100/70 $\mathrm{mmHg}$, pulse $80 x /$ minute, respiratory 20x/minute, with afebrile temperature. The patient was monitored in the recovery room for three hours. During monitoring in the recovery room, the patient's general condition was good, with good vital signs and no complaints of bleeding. The patient was later moved to the wardroom. At the next day's visit, the general condition of the patient was good. She was allowed to go home. One week later, the patient's general condition was normal, with vital signs of blood pressure 120/80 mmHg, smooth defecation (bowel movements) and urination, no bleeding, no complaints of pain, and no complaints against PAIUDs that were mounted. Ultrasound results showed a clean uterus with visible PAIUD in situ.

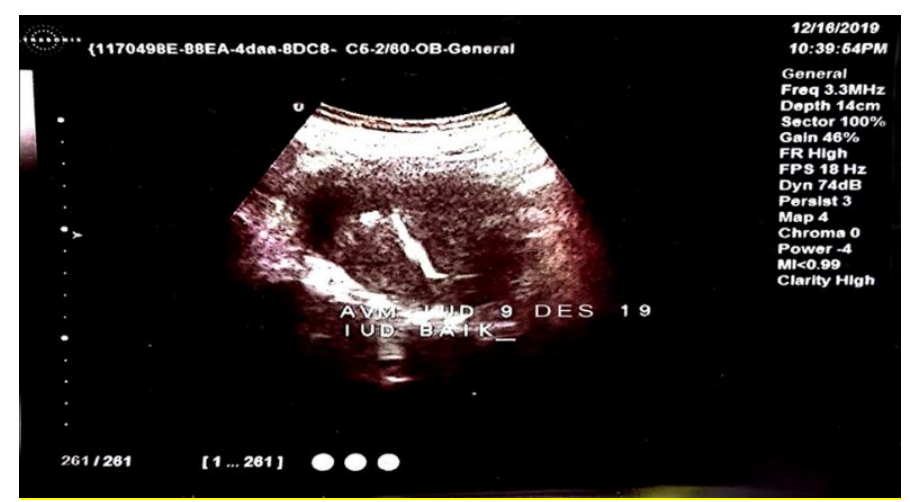

Figure 2. Results of the 7th-day MVA ultrasound with PAIUD in situ

The patient came in control, waiting for menstruation. She got her menstruation about two months after MVA. Her menstruation lasted for 4 days, with a normal amount of blood. There were no complaints about the IUFD, no pain during menstruation, and no pain during sexual intercourse. 


\section{DISCUSSION}

Manual Vacuum Aspiration is the standard measure for evacuation of the uterine cavity in cases of miscarriage in the first trimester. ${ }^{5}$ In this case report, evacuation of the uterine cavity with MVA is carried out at 18 week-gestation. The uterine cavity was much larger than the 12-14 week gestational age, so there was a concern that unclean tissue would occur. The implementation of MVA was carried out in the operating room with Total Intravenous Anesthesia (TIVA) so that the respondent was calm since previously, she had panicked, experienced bleeding, and repeated abortions. In addition, as the respondent's age was more than 40 years old, the use of TIVA was under the supervision of an anesthesiologist. TIVA is an anesthetic that is commonly used in cases of uterine cavity evacuation. The parenteral opioid used was pethidine $50 \mathrm{mg}$. Sedation such as intravenous midazolam was also used when it was needed. ${ }^{4}$

In this case, the bleeding and tissue discharge occurred, with the administration of $100 \mu \mathrm{g}$ misoprostol first. Thus, the diagnosis turned into incomplete abortion. The evacuation of the uterine cavity as an incomplete abortion was performed with MVA. The use of a dose of $100 \mathrm{~g}$ misoprostol orally was chosen because the respondent experienced bleeding. Larger doses of misoprostol ( $400 \mathrm{~g})$ were chosen either orally or vaginally if cervical ripening was required. ${ }^{11}$

Misoprostol used for the evacuation of the uterine cavity required additional use of MVA in $17 \%$ of subjects $^{12}$. The dose of misoprostol in this case report differed from a study comparing the use of misoprostol against MVA as a treatment for evacuation of the uterine cavity. The amount of misoprostol used was 600 $\mu \mathrm{g}$ at gestational age less than 13 weeks. ${ }^{13,14}$

The results were obtained when the control patient experienced a clean uterus with visible PAIUD in situ one week later. Begum et al., reported that MVA was recommended in Bangladesh for the management of incomplete abortion. It is because the MVA procedure is safe, effective, faster, cheaper, minimal pain, shorter hospital stay, and less risk of uterine perforation. Thus, the use of MVA in incomplete abortion reduced maternal morbidity and mortality. ${ }^{8}$ In line with the research of Odland et al., MVA has begun to be practiced in several hospitals in Malawi and has even become the leading management of incomplete abortion cases due to the minimal complications it caused..$^{15}$

In this case, the MVA procedure was safe, effective, and faster, only requiring 10 minutes in the process, even though the uterine cavity was quite large due to 18 weeks gestation. At the time of evaluation, the uterine cavity was clear, and PAIUD was applied. Further, Blandine et al., reported that MVA is effective in managing complications in early pregnancy. ${ }^{9}$ It serves minimal complications of the incidence of uterine perforation, bleeding, and the remaining tissue after the MVA action. MVA is a safe, easy-to-do, and costeffective procedure that benefits both patients and health facilities..$^{4,6,9}$ In this case report, the magnitude of 18 weeks gestation did not become an obstacle to cleaning the uterine cavity using the MVA procedure. MVA's action is a procedure that is more effective than sharp curettage, which Brown et al., MVA also conveyed to be cheaper with shorter hospital stays. ${ }^{16}$ More importantly, MVA results in a smaller amount of bleeding, fewer serious complications, aside from being quick and easy to work on, and minimal pain compared to sharp curettage. ${ }^{16}$

MVA can be done more quickly. More minimal pain and a smaller amount of bleeding are also obtained from the statement of Odland et al., MVA procedure is an evacuation of the uterine cavity in cases of incomplete abortion, up to 14 weeks gestation, and sufficient use of local anesthesia or analgesia. ${ }^{15}$ In addition, MVA can be done in outpatient polyclinics and places with minimal human and equipment resources as it does not require sedation and electrical devices.,37 It is even possible that MVA can be done by trained midwives and nurses. ${ }^{18,19}$ The WHO recommends that AVM is a safer procedure than dilation and curettage for termination of pregnancy. ${ }^{20}$ The safety of MVA procedures is also conveyed in several scientific publications that have been submitted. In addition, vacuum aspiration manually or electrically is as good as the evacuation of the uterine cavity in cases of the first-trimester miscarriage. ${ }^{21}$

\section{CONCLUSION}

Manual Vacuum Aspiration as a procedure for evacuation of the uterine cavity in IUFD at 18 weeks gestation, gave good, safe, effective, clean, and fast results in the process of evacuation. The MVA procedure could be recommended as an evacuation of uterine cavities in cases of miscarriage with a gestational age of more than 14 weeks. 
There is no conflict of interest in this study.

\section{REFERENCES}

1. Padrón L. Manual Compared with Electric Vacuum Aspiration for Treatment of Molar Pregnancy. Obstet. Gynecol. 2018;131(4): 652-659. https://doi.org/10.1097/AOG.0000000000002522

2. Soewarto S. Kematian Janin. PT Bina Pustaka, 2016.

3. Odland ML. Decrease in Use of Manual Vacuum Aspiration in Postabortion Care in Malawi: A cross-Sectional Study from Three Public Hospitals. PLoS One 9; 2014: 2008-2012. https://doi.org/10.1371/journal.pone.0100728

4. Azman A, Sakri NAM, Mohd Kusni NA, Mansor NH \& Zakaria ZA. Manual vacuum aspiration: a safe and effective surgical management of early pregnancy loss. Int. J. Reprod. Contraception, Obstet. Gynecol. 8, 2256 (2019). https://doi.org/10.18203/2320-1770.ijrcog20192413

5. Anozie OB, Nwafor JI, Ukaegbe CI, Esike CU, Anozie RO, Lawani LO, et al. A 5-Year Retrospective Study on the Use of Manual Vacuum Aspiration in the Federal Teaching Hospital Abakaliki. Open J. Obstet Gynecol; 2019; 9(2): 142-148. https://doi.org/10.4236/ojog.2019.92015

6. Zommere I, Umaru A \& Mulbagal K. Should Manual Vacuum Aspiration for Miscarriage be the Preferred Option Over a Surgical Evacuation? Eur J. Obstet Gynecol Reprod Biol. 2016: 206.

7. Speedie J \& Robson S. The Evolution of a One-stop' Out Patient Manual Vacuum Aspiration Service for Termination of Pregnancy. BMJ Sex Reprod Heal. 2018; 44: 58-60. https://doi.org/10.1136/bmjsrh-2017101806

8. Begum S, Rashid M \& Jahan A. Clinical Study on Management of Incomplete Abortion by Manual Vacuum Aspiration (MVA). J Enam Med Coll. 2012; 2(1): 24-28. https://doi.org/10.3329/jemc.v2i1.11918

9. Blandine T. Oral Misoprostol as First-line Care for Incomplete Abortion in Burkina Faso. Int J Gynecol Obstet. 2012; 119(2): 166-169. https://doi.org/10.1016/j.ijgo.2012.05.036

10. Pillai M. Introduction of a Manual Vacuum Aspiration Service: A model of Service within a NHS Sexual Health Service. J Fam Plan Reproduction Health Care. 2015; 41: 27-32. https://doi.org/10.1136/jfprhc-2013-100700

11. Revankar VM. Tablet Misoprostol as a Cervical Priming Agent Prior to Surgical Abortion. Int J Reproduction Contraception Obstet Gynecol. 2017; 6(7): 3004. http://dx.doi.org/10.18203/2320-1770.ijrcog20172924

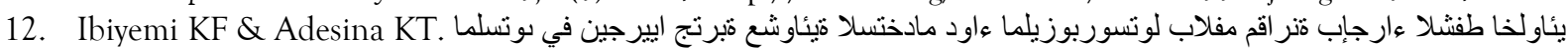

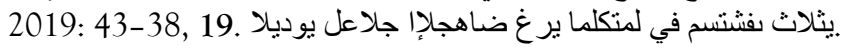

13. Nwafor JI. Misoprostol Versus MVA for Treatment. Niger. JCP. 2020: 638-646. https://doi.org/10.4103/njcp.njcp_379_19

14. Ahmed SK, Ashraf R \& Khaloon LE. Comparison of Sublingual Misoprostol and Manual Vacuum Aspiration for the Treatment of Incomplete Abortion in First Trimester in Terms of Frequency of Decreased Haemoglobin Levels. JRMC. 2017; 21(3): 208-210.

15. Odland ML. The Use of Manual Vacuum Aspiration in the Treatment of Incomplete Abortions: A Descriptive Study from Three Public Hospitals in Malawi. Int J Environ Res Public Health. 2018; 15(2): 370. https://doi.org/10.3390/ijerph15020370

16. Brown HC. Management of Incomplete Abortion in South African. BJOG An Int J Obstet Gynaecol. 2003; 110(4): 371-377. https://doi.org/10.1046/j.1471-0528.2003.t01-1-02036.x

17. Sharma M. Manual Vacuum Aspiration: An Out Patient Alternative for Surgical Management of Miscarriage. Obstet Gynaecol. 2015; 17(3): 157-161. https://doi.org/10.1111/tog.12198

18. Bourret KM. Midwives' Integration of Post Abortion Manual Vacuum Aspiration in the Democratic Republic of Congo: A Mixed Methods Case Study \& Positive Deviance Assessment. BMC Health Serv Res. 2020; 20: 1 16. https://doi.org/10.1186/s12913-020-05997-7

19. Sheldon S \& Fletcher J. Vacuum Aspiration for Induced Abortion Could be Safely and Legally Performed by Nurses and Midwives. J Fam Plan Reprod Heal Care. 2017; 43(4): 260-264. https://doi.org/10.1136/jfprhc2016-101542

20. Pawde AA, Ambadkar A \& Chauhan AR. A Study of Incomplete Abortion Following Medical Method of Abortion (MMA). J Obstet Gynecol India. 2016; 66(4): 239-243. https://doi.org/10.1007/s13224-015-0673-1

21. Dean G. Manual Compared with Electric Vacuum Aspiration for Abortion at Less than 6 Weeks of Gestation. Obstet Gynecol. 2015; 125(5): 1121-1129. https://doi.org/10.1097/AOG.0000000000000787 